\title{
KETERKAITAN HUBUNGAN ANTARA KEMAMPUAN KOMUNIKASI DAN PENALARAN MATEMATIS SISWA
}

\author{
Hayatun Nufus ${ }^{1}$, Rezi Ariawan ${ }^{2}$ \\ ${ }^{1}$ Dosen Pendidikan Matematika FTK UIN Suska Riau \\ ${ }^{2}$ Dosen Pendidikan Matematika Universitas Islam Riau \\ 1hayatun.nufus@uin-suska.ac.id, ${ }^{2}$ reziariawan@edu.uir.ac.id
}

\begin{abstract}
ABSTRAK
Penelitian ini mengkaji hubungan antara kemampuan komunikasi dan penalaran matematis siswa. Penelitian ini dilaksanakan di Pekanbaru pada semester genap tahun ajaran 2011/2012. Populasi pada penelitian ini adalah seluruh siswa SMP kelas VII di Pekanbaru yang berjumlah 84 sekolah pada tahun ajaran 2011/2012 dan dengan subjek penelitian adalah tiga SMP yang masing-masing mewakili sekolah level tinggi, sedang, dan rendah. Teknik pengambilan sekolah sebagai sampel menggunakan stratified dan purposive sampling serta instrumen yang digunakan berupa soal tes kemampuan komunikasi matematis dan kemampuan penalaran matematis. Berdasarkan hasil uji korelasi product moment yang dilanjutkan dengan dengan uji $t$, dapat disimpulkan dua hal. Pertama, secara keseluruhan, terdapat hubungan yang signifikan antara kemampuan komunikasi dan penalaran matematis siswa. Kedua, jika diperhatikan berdasarkan level sekolah, terdapat hubungan yang signifikan antara kemampuan komunikasi dan penalaran matematis siswa untuk sekolah level tinggi, sedang, dan rendah.
\end{abstract}

Kata Kunci : quick on the draw, pembelajaran kooperatif, komunikasi matematis, penalaran matematis, hubungan komunikasi dan penalaran matematis

\begin{abstract}
This study explained the correlation between student's mathematical communication and reasoning abilitiy. This research was conducted in Pekanbaru in the even semester of academic year 2011/2012. The population in this study were all students of SMP class VII in Pekanbaru which amounted to 84 schools in the academic year 2011/2012 and with the subject of research are three junior high school, each representing high, medium, and low school. The technique of taking school as sample using stratified and purposive sampling as well as instrument used in the form of test of mathematical communication ability and mathematical reasoning ability. Based on the results of corerelation product moment and $\mathrm{t}$ test, it can be concluded two things. First, as a whole, there is a significant correlation between student's mathematical communication ability and mathematical reasoning ability. Secondly, when considered at the school level, there is a significant correlation between mathematical communication ability and mathematical reasoning ability for high, medium, and low-level schools.
\end{abstract}

Keywords: quick on the draw, cooperative learning, mathematical communication, mathematical reasoning, correlation between mathematical communication and reasoning 


\section{A. PENDAHULUAN}

\section{Latar Belakang}

Tujuan pemberian mata pelajaran matematika dirinci untuk setiap jenjang pendidikan. Dua diantara lima tujuan pemberian mata pelajaran matematika untuk Sekolah Menengah Pertama (SMP)/Madrasah Tsanawiyah (MTs) adalah agar siswa memiliki kemampuan komunikasi dan penalaran matematis (Departemen Pendidikan Nasional, 2006). Hal ini senada dengan yang dikemukakan oleh Wahyudin (2008), yaitu bahwa kemampuan menggunakan penalaran sangat penting untuk memahami matematika dan menjadi bagian yang tetap dari pengalaman matematik para siswa sejak pra-TK hingga kelas 12. Bernalar secara matematis merupakan kebiasaan pikiran, dan seperti semua kebiasaan lainnya, inipun dibangun lewat penggunaan yang terus menerus di dalam berbagai konteks.

Kemampuan penalaran ini erat kaitannya dengan kemampuan komunikasi matematis. Ketika siswa ingin menyelesaikan suatu persoalan matematis melalui kegiatan bernalar, maka tentu terlebih dahulu ia harus mampu memiliki kemampuan dalam membaca dengan pemahaman suatu representasi matematis tertulis (salah satu indikator kemampuan komunikasi matematis) untuk kemudian menggunakan kemampuan penalaran matematisnya dalam menyelesaikan persoalan. Selanjutnya, agar pemikiran matematis yang dihasilkannya lewat bernalar dapat tersampaikan secara baik kepada teman dan gurunya, maka ia perlu memiliki kemampuan komunikasi matematis yang mendukung pula, baik itu secara lisan maupun tertulis.

Komunikasi adalah bagian esensial dari matematika dan pendidikan matematika. Komunikasi merupakan cara berbagi gagasan dan mengklarifikasi pemahaman. Proses komunikasi membantu membangun makna dan kelanggengan gagasan-gagasan serta agar gagasan-gagasan tersebut dapat diketahui publik. Saat para siswa ditantang untuk berpikir dan bernalar tentang matematika serta untuk mengkomunikasikan hasil-hasil pemikiran mereka itu pada orang lain secara lisan atau tertulis, mereka belajar untuk menjadi jelas dan meyakinkan (Wahyudin, 2008).

Walaupun kemampuan penalaran dan komunikasi matematis penting untuk dimiliki oleh siswa, namun pada kenyataannya kedua kemampuan matematis tersebut belumlah memuaskan. Sumarmo (Siregar, 2011) menemukan bahwa keadaan skor kemampuan siswa dalam penalaran matematis masih rendah. Penemuan Wahyudin (Siregar, 2011) turut menegaskan bahwa salah satu kelemahan yang ada pada siswa 
antara lain kurang memiliki kemampuan nalar yang logis dalam menyelesaikan persoalan atau soal-soal matematika.

Berdasarkan uraian di atas, peneliti tertarik untuk melakukan pengkajian lebih dalam tentang kaitan hubungan antara kemampuan komunikasi matematis dengan kemampuan penalaran matematis siswa. Selanjutnya, salah satu hal yang dapat mempengaruhi tingkat kedua kemampuan ini adalah kecerdasan siswa. Berbicara tentang kecerdasan siswa, tingkat kecerdasan siswa beragam, ada yang pandai, sedang-sedang saja, dan lemah. Hal ini didukung oleh Galton (Ruseffendi, 2006) yang mengemukakan bahwa dari sekelompok siswa yang dipilih secara sebarang (tidak dipilih secara khusus), akan dijumpai siswa yang berkemampuan tinggi, sedang, dan rendah yang menyebar secara berdistribusi normal. Pada umumnya, siswa berkemampuan tinggi cenderung berada di sekolah level tinggi, begitu pula dengan siswa level sedang dan rendah akan cenderung berada di sekolah level sedang dan rendah.

\section{Rumusan Masalah}

Berdasarkan penjelasan pada latar belakang, rumusan masalah yang digunakan sebagai pedoman pelaksanaan tindakan dalam penelitian ini adalah:

1. Apakah terdapat hubungan antara kemampuan komunikasi matematis dan kemampuan penalaran matematis siswa secara keseluruhan (tanpa memandang level sekolah)?

2. Apakah terdapat hubungan antara kemampuan komunikasi matematis dan kemampuan penalaran matematis siswa sekolah level tinggi?

3. Apakah terdapat hubungan antara kemampuan komunikasi matematis dan kemampuan penalaran matematis siswa sekolah level sedang?

4. Apakah terdapat hubungan antara kemampuan komunikasi matematis dan kemampuan penalaran matematis siswa sekolah level rendah?

\section{B. METODE PENELITIAN}

\section{Lokasi, Waktu dan Subjek Penelitian}

Penelitian ini dilaksanakan di Pekanbaru, Riau pada bulan Februari sampai dengan Maret 2012. Populasi dalam penelitian ini adalah seluruh siswa SMP kelas VII di Pekanbaru pada tahun ajaran 2011/2012. Dari seluruh SMP yang ada, dipilih 
tiga sekolah dengan teknik pengambilan sampel stratified sampling dan purposive sampling yang masing-masing mewakili sekolah dengan level tinggi, sedang, dan rendah. Pengelompokkan level sekolah didasarkan pada hasil Ujian Nasional tahun 2010/2011 untuk SMP. Dari 84 SMP Negeri dan Swasta se-Pekanbaru, peringkat 1-28 dikategorikan sebagai sekolah level tinggi, peringkat 29-56 sebagai sekolah level sedang, dan peringkat 57-84 sebagai sekolah level rendah. Sekolah level tinggi diwakili oleh SMP Negeri A, level sedang diwakili SMP Negeri B, dan level rendah diwakili SMP Swasta C (nama sekolah bukan nama sebenarnya).

SMP Negeri A adalah sekolah yang terletak di pusat Kota Pekanbaru dan berada dalam kompleks sekolah dan perkantoran. Sekolah ini berada pada peringkat 6 dalam perolehan nilai Ujian Nasional SMP se-Pekanbaru yang selalu menjadi salah satu tujuan favorit bagi siswa tamatan SD dalam melanjutkan studi. Selain itu, sekolah ini juga memiliki sarana dan prasarana belajar yang sangat mendukung serta memiliki input siswa yang cenderung berkemampuan kognitif tinggi. Berbeda dengan SMP Negeri A, SMP Negeri B terletak di antara kompleks perumahan dengan lahan yang tidak seluas SMP Negeri A. Sekolah ini juga tidak memiliki sarana dan prasarana belajar yang selengkap SMP Negeri A, namun dapat dikatakan cukup untuk memfasilitasi kegiatan belajar siswa, serta memiliki input siswa yang cenderung dengan kemampuan kognitif sedang dan lebih beragam daripada SMP Negeri A. Pada urutan peroleh hasil Ujian Nasional, sekolah ini berada pada peringkat 32. SMP Swasta C terletak di daerah pertokoan yang berada dalam satu kawasan dengan SMA dan SMK di bawah satu yayasan yang sama. Sekolah ini cenderung memiliki input siswa dengan kemampuan kognitif menengah ke bawah dan berada pada peringkat 72 dalam perolehan hasil Ujian Nasional.

\section{Instrumen Penelitian}

Instrumen penelitian yang digunakan adalah berupa instrumen tes komunikasi dan penalaran matematis. Adapun data yang digunakan diperoleh melalui kegiatan tes, yaitu dengan melakukan tes yang terdiri atas enam soal (berupa soal kemampuan komunikasi dan penalaran matematis), dengan rincian indikator yang digunakan pada penelitian ini untuk kedua kemampuan sebagai berikut: 
a. Indikator Kemampuan Komunikasi Matematis (Sumarmo, 2010: 5-6)

a. Memodelkan situasi-situasi dengan menggunakan tulisan, baik secara konkret, gambar, garif, atau metode-metode aljabar

b. Membaca dengan pemahaman suatu representasi matematika tertulis

c. Menjelaskan ide atau situasi matematis secara tertulis

d. Mengungkapkan kembali suatu uraian matematika dalam bahasa sendiri

b. Indikator Kemampuan Penalaran matematis

a. Menggunakan pola dan hubungan untuk menganalisis situasi matematis

b. Memberikan penjelasan dengan menggunakan model, fakta, sifat-sifat atau hubungan

c. Menyusun pembuktian langsung atau tak langsung

d. Menarik kesimpulan logis

e. Melaksanakan perhitungan berdasarkan aturan atau rumus tertentu

f. Memperkirakan jawaban dan proses solusi

\section{Teknik Pengumpulan Data dan Teknik Analisis Data}

Pengolahan dan analisis data dilakukan dengan menggunakan uji bivariate correlation, yaitu korelasi Pearson Product Moment, karena data yang diperoleh berupa data interval untuk mencari hubungan antara dua variabel, yaitu kemampuan komunikasi dan penalaran matematis siswa. Pengolahan data ini menggunakan bantuan Ms. Excel.

Langkah pertama yang dilakukan adalah melakukan uji koefisien korelasi menggunakan rumus Pearson/Product Moment :

$$
r_{x y}=\frac{\Sigma x y}{\sqrt{\left(\Sigma x^{2}\right)\left(\Sigma y^{2}\right)}}
$$

Adapun pedoman untuk memberikan interpretasi terhadap koefisien korelasi yang diperoleh dari hasil perhitungan dapat dilihat pada tabel 1.

Sementara untuk melihat koefisien korelasi yang dihasilkan signifikan atau tidak, maka dilanjutkan dengan menggunakan uji t.

$$
t_{\text {hitung }}=\frac{r \sqrt{n-2}}{\sqrt{1-r^{2}}}
$$


Tabel 1.

Pedoman Interpretasi terhadap Koefisien Korelasi

\begin{tabular}{cc}
\hline Interval Koefisien & Tingkat Hubungan \\
\hline $0,00-0,199$ & Sangat rendah \\
$0,20-0,399$ & Rendah \\
$0,40-0,599$ & Sedang \\
$0,60-0,799$ & Kuat \\
$0,80-1,000$ & Sangat kuat \\
\hline
\end{tabular}

Sumber: Sugiyono (2011: 231)

Jika $\mathrm{t}_{\text {hitung }} \geq \mathrm{t}_{\text {tabel }}$, maka $\mathrm{H}_{0}$ diterima, artinya terdapat hubungan/korelasi yang signifikan dan sebaliknya(taraf signifikansi 0.05). Jika koefisien korelasi signifikan, besarnya pengaruh antar variabel dapat dicari dengan koefisien penentu (determinasi), dengan rumus :

$$
\mathrm{KP}=(\mathrm{r})^{2} \times 100 \%
$$

Langkah selanjutnya adalah menghitung rata-rata kemampuan setiap peserta didik untuk kedua kemampuan (Kemampuan komunikasi dan penalaran matematis), lalu dilanjutkan dengan mengolah data menggunakan uji uji prasyarat pada analisis data model regresi linier. Adapun rumus yang digunakan berdasarkan Riduwan dan Sunarto (2013: 97):

$$
y^{\prime}=a+b x
$$

dengan

$\mathrm{b}=\frac{\mathrm{n} \cdot \sum \mathrm{XY}-\sum \mathrm{X} \cdot \sum \mathrm{Y}}{\mathrm{n} \cdot \sum \mathrm{X}^{2}-\left(\sum \mathrm{X}\right)^{2}}$ dan $\mathrm{a}=\frac{\sum \mathrm{Y}-\mathrm{b} \cdot \sum \mathrm{X}}{\mathrm{n}}$

nilai b merupakan nilai arah sebagai penentu ramalan yang menunjukkan nilai peningkatan/keadaan berbanding lurus $(+)$ atau nilai penurunan/keadaan berbanding terbalik (-).

\section{HASIL DAN PEMBAHASAN}

Setelah melakukan tes kemampuan komunikasi dan penalaran matematis, diperolehlah data kemampuan komunikasi dan penalaran matematis siswa untuk setiap level sekolah. Data ini kemudian dianalisis melalui dua tahapan, yaitu penyajian secara statistik deskriptif dan pengujian secara statistik.

\section{Statistik Deskriptif Kemampuan Komunikasi dan penalaran matematis}

Rangkuman perhitungan data statistik deskriptif untuk kemampuan komunikasi dan penalaran matematis siswa baik secara keseluruhan maupun per-level sekolah dapat dilihat pada Tabel 2 berikut: 
Tabel 2.

Statistik Deskriptif Kemampuan Penalaran dan Komunikasi Matematis Siswa

\begin{tabular}{ccccccc}
\hline \multicolumn{2}{c}{ Kelompok } & $\mathrm{N}$ & $X_{\text {maks }}$ & $X_{\min }$ & $\bar{X}$ & $S$ \\
\hline Secara & Penalaran & 111 & 36 & 0 & 15,5 & 9,2 \\
Keseluruhan & Komunikasi & 111 & 15 & 0 & 4,7 & 3,7 \\
Sekolah level & Penalaran & 29 & 32 & 4 & 16,6 & 6,3 \\
Tinggi & Komunikasi & 29 & 15 & 0 & 6,4 & 3,6 \\
Sekolah Level & Penalaran & 40 & 36 & 10 & 23 & 7,4 \\
Sedang & Komunikasi & 40 & 15 & 2 & 7,1 & 3,0 \\
Sekolah Level & Penalaran & 42 & 15 & 0 & 7,5 & 5,2 \\
Rendah & Komunikasi & 42 & 4 & 0 & 1,4 & 1,1 \\
\hline
\end{tabular}

Skor ideal penalaran matematis $=36$

Skor ideal komunikasi matematis $=16$

Berdasarkan Tabel 2, dapat diketahui bahwa secara numeris kemampuan penalaran matematis siswa secara keseluruhan tergolong rendah. Hal ini karena ratarata secara keseluruhan tidak mencapai setengah dari nilai maksimal matematis, yaitu 18. Hal ini juga terjadi untuk kemampuan penalaran matematis siswa pada sekolah level tinggi dan rendah. Namun sebaliknya untuk sekolah level sedang, karena ketercapaiannya secara klasikal adalah 63,8\% (23 dari 36).

Selanjutnya, untuk kemampuan komunikasi matematis, tidak ada satupun yang memperoleh rata-rata di atas 50\% dari skor ideal komunikasi matematis, yaitu 8 . Ini berarti, baik secara keseluruhan maupun untuk tiap level sekolah, kemampuan komunikasi matematis siswa masih tergolong rendah.

Selain itu, baik secara keseluruhan maupun perlevel sekolah, selalu hampir ada siswa yang tidak mampu sama sekali dalam menyelesaikan soal kemampuan komunikasi dan penalaran matematis. Hal ini dilihat dari skor 0 yang diperoleh siswa. Namun, untuk sekolah level sedang dan secara keseluruhan selalu ada siswa yang memperoleh skor maksimal atau nyaris maksimal.

\section{Uji Korelasi Pearson Product Momen dan Koefisien Penentu untuk Setiap}

\section{Level}

Rangkuman perhitungan uji korelasi kemampuan komunikasi dan penalaran matematis siswa baik secara keseluruhan maupun per-level sekolah dapat dilihat pada Tabel 4.

$\mathrm{H}_{0}$ : Tidak ada hubungan antara kemampuan komunikasi dan penalaran matematis $\mathrm{H}_{1}$ : Terdapat hubungan antara kemampuan komunikasi dan penalaran matematis 
Tabel 3.

Uji Korelasi Pearson Product Momen untuk Setiap Kelompok

\begin{tabular}{cccccc}
\hline Level Kemampuan & $\begin{array}{c}\text { Nilai } \\
\text { Korelasi }\left(r_{x y)}\right.\end{array}$ & $\mathrm{KP}=r^{2}$ & $\begin{array}{c}\text { Data } \\
t \text { Hitung }\end{array}$ & $\begin{array}{c}\text { Data } \\
t \text { Tabel }\end{array}$ & Keterangan \\
\hline Secara keseluruhan & 0,803 & $0,65(65 \%)$ & 14,042 & 1,658 & Tolak $\mathrm{H}_{0}$ \\
Sekolah level tinggi & 0,714 & $0,51(51 \%)$ & 5,2916 & 1,701 & Tolak $\mathrm{H}_{0}$ \\
Sekolah level sedang & 0,598 & $0,36(36 \%)$ & 4,5948 & 1,684 & Tolak $\mathrm{H}_{0}$ \\
Sekolah level rendah & 0,774 & $0,60(60 \%)$ & 7,7234 & 1,684 & Tolak $\mathrm{H}_{0}$ \\
\hline
\end{tabular}

Tabel 3 memperlihatkan nilai signifikansi uji korelasi antara kemampuan komunikasi dan penalaran matematis siswa, baik secara keseluruhan maupun perlevel sekolah. Berdasarkan data di atas, setiap skor $t$ hasil perhitungan selalu lebih dari nilai $t$ tabel. Ini berarti bahwa terdapat hubungan antara kemampuan komunikasi dan penalaran matematis siswa baik secara keseluruhan maupun perlevel sekolah.

Nilai korelasi hitung secara keseluruhan adalah 0,803 menyatakan bahwa hubungan yang terjadi sangatlah kuat. Selanjutnya, nilai KP (Koefisien Penentu) sebesar $65 \%$, mengungkapkan bahwa besarnya sumbangan kemampuan penalaran matematis terhadap naik atau turunnya kemampuan komunikasi matematis siswa adalah sebesar $65 \%$. Sedangkan 35\% merupakan sumbangan dari faktor lainnya.

Nilai korelasi hitung untuk sekolah level tinggi adalah 0,714 menyatakan bahwa hubungan yang terjadi termasuk dalam kategori kuat. Selanjutnya, nilai KP (Koefisien Penentu) sebesar $51 \%$, mengungkapkan bahwa besarnya sumbangan kemampuan penalaran matematis terhadap naik atau turunnya kemampuan komunikasi matematis siswa adalah sebesar 51\%. Sedangkan 49\% merupakan sumbangan dari faktor lainnya.

Nilai korelasi hitung untuk sekolah level sedang adalah 0,598 menyatakan bahwa hubungan yang terjadi termasuk dalam kategori sedang. Selanjutnya, nilai KP (Koefisien Penentu) sebesar $36 \%$, mengungkapkan bahwa besarnya sumbangan kemampuan penalaran matematis terhadap naik atau turunnya kemampuan komunikasi matematis siswa adalah sebesar 36\%. Sedangkan 64\% merupakan sumbangan dari faktor lainnya.

Nilai korelasi hitung untuk sekolah level rendah adalah 0,774 menyatakan bahwa hubungan yang terjadi termasuk dalam kategori kuat. Selanjutnya, nilai KP (Koefisien Penentu) sebesar $60 \%$, mengungkapkan bahwa besarnya sumbangan kemampuan penalaran matematis terhadap naik atau turunnya kemampuan komunikasi matematis siswa adalah sebesar 60\%. Sedangkan 40\% merupakan sumbangan dari faktor lainnya, berdasarkan Supranto (2008: 163). 


\section{Persamaan Regresi untuk Setiap Level}

Karena berdasarkan hasil uji signifikansi diperoleh bahwa terjadi korelasi yang signifikan antara kemampuan komunikasi dan penalaran matematis baik secara keseluruhan maupun untuk tiap level sekolah, maka perlu dilakukan analisis regresi. Hal ini senada dengan yang dikatakan Riduwan dan Sunarto (2013: 97) bahwa analisis korelasi yang tidak dilanjutkan dengan analisis regresi adalah korelasi yang kedua variabelnya tidak mempunyai hubungan fungsional dan sebab akibat. Adapun rangkuman perhitungan persamaan regresi linier sederhana untuk setiap level sekolah dan secara keseluruhan dapat dilihat pada tabel 4 berikut:

Tabel 4.

Persamaan Regresi Linier Sederhana

\begin{tabular}{ccc}
\hline Level Kemampuan & $\mathrm{n}$ & Persamaan Regresi \\
\hline Secara Keseluruhan & 111 & $\mathrm{y}=0+1,9739 \mathrm{x}$ \\
Sekolah Level Tinggi & 29 & $\mathrm{y}=0,0035+1,2466 \mathrm{x}$ \\
Sekolah Level Sedang & 40 & $\mathrm{y}=-0,1114+1,4850 \mathrm{x}$ \\
Sekolah Level Rendah & 42 & $\mathrm{y}=-0,0005+3,6561 \mathrm{x}$ \\
\hline
\end{tabular}

Berdasarkan data pada tabel 4, nilai b baik secara keseluruhan maupun untuk tiap level sekolah bernilai positif. Hal ini berarti hubungan yang terjadi adalah berbanding lurus. Artinya, semakin tinggi kemampuan komunikasi matematis siswa, maka akan semakin tinggi pula kemampuan penalaran matematisnya, begitu pula sebaliknya. Dengan kata lain, tingkat kemampuan komunikasi matematis siswa secara keseluruhan berkontribusi secara postif sebesar $65 \%$ terhadap kemampuan penalaran matematisnya, begitu pula sebaliknya. Hal yang sama untuk sekolah level tinggi (51\%), sekolah level sedang (36\%), dan sekolah level rendah (60\%).

Berdasarkan uraian di atas, jelas bahwa memang kemampuan penalaran matematis dan komunikasi matematis sangat berhubungan erat dengan persentase keterkaitannya masing-masing. Selanjutnya, setelah dilakukan analisis terhadap jawaban yang diberikan siswa, dapat diketahui bahwa secara garis besar, kesalahankesalahan yang terjadi sehingga membuat skor kemampuan penalaran matematis siswa rendah antara lain:

a. Siswa kurang bisa dalam menyatakan permasalahan dalam bentuk soal cerita ke dalam bentuk diagram venn. Ini terlihat pada jawaban siswa untuk soal nomor 1a. 
b. Siswa salah dalam menginterpretasikan maksud soal. Ini terlihat pada jawaban siswa untuk soal nomor $1 \mathrm{~b}$ dan 4 . Pada soal nomor $1 \mathrm{~b}$, yang ditanyakan adalah jumlah keluarga, sementara yg siswa hitung adalah jumlah persen. Sedangkan pada soal nomor 4, yang ditanyakan adalah banyak anggota himpunan, sementara yang siswa tulis adalah daftar anggota himpunan.

c. Siswa salah menginterpretasikan mana yang merupakan himpunan semesta, dan mana yang merupakan himpunan bagian, sehingga turut salah dalam mendaftarkan anggota pada masing-masing himpunan yang berakibat pada kesalahan dalam menyatakan persoalan ke dalam bentuk diagram venn. Ini terlihat pada jawaban siswa untuk soal nomor $2 \mathrm{a}$ dan $2 \mathrm{~b}$.

d. Siswa tidak tahu hubungan apa yang terjadi pada himpunan yang telah digambarkannya dalam bentuk diagram venn. Ini terlihat pada jawaban siswa untuk soal nomor $2 \mathrm{c}$.

e. Siswa kurang memahami konsep hubungan antar himpunan dan jenis-jenisnya, sehingga kesulitan dalam membuat kemungkinan-kemungkinan hubungan yang dapat terjadi antarhimpunan. Ini terlihat pada jawaban siswa untuk soal nomor 3.

f. Siswa keliru dalam mengenali lambang himpunan gabungan dan irisan. Ini terlihat pada jawaban siswa untuk soal nomor 4

g. Siswa salah dalam menganalisis anggota pada suatu himpunan. Ini terlihat pada jawaban siswa untuk soal nomor 5a

h. Siswa kurang lengkap dan jelas dalam mengemukakan alasan dalam memperkuat jawaban yang ditulis. Ini terlihat pada jawaban siswa untuk soal nomor 5b.

Berikut adalah cuplikan jawaban siswa untuk soal nomor 3, 4, dan 5 dalam kemampuan penalaran matematis:

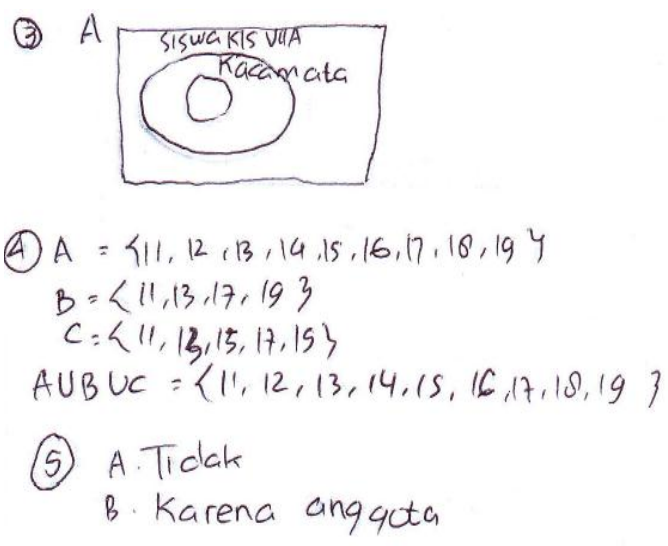

Gambar 1.

Jawaban Siswa dalam Kemampuan Penalaran Matematis 
Adapun bunyi pertanyaan untuk soal nomor 3, 4, dan 5 adalah:

c. Diketahui $\mathrm{A}=\{$ himpunan siswa di kelas VII A $\}$

$$
\mathrm{B}=\{\text { Himpunan siswa kelas VII yang berkacamata\} }
$$

a. Nyatakanlah kemungkinan-kemungkinan hubungan yang dapat terjadi antara himpunan A dan B tersebut ke dalam diagram yang sesuai.

b. Sebutkanlah kemungkinan-kemungkinan tersebut.

d. Perhatikan himpunan-himpunan berikut:

$\mathrm{A}=\{$ himpunan bilangan asli antara 10 dan 20$\}$

$\mathrm{B}=\{$ himpunan bilangan prima antara 10 dan 20$\}$

$\mathrm{C}=\{$ himpunan bilangan ganjil antara 10 dan 20$\}$

Berapa banyakkah anggota himpunan $A \cup B \cup C$ ? Jelaskan jawabanmu.

e. $\mathrm{X}$ adalah himpunan bilangan asli yang kurang dari 1 dan $\mathrm{Y}$ adalah himpunan bilangan cacah yang kurang dari 1 .

a. Apakah dapat disimpulkan $\mathrm{X}=\mathrm{Y}$ ?

b. Berikan alasan untuk jawabanmu.

Pada gambar di atas, pada soal nomor 3, tampak bahwa siswa hanya bisa menentukan satu kemungkinan saja yang dianggapnya sesuai untuk menentukan hubungan antara kedua himpunan, padahal masih terdapat empat kemungkinan lainnya. Hal ini karena siswa kurang menguasai konsep hubungan antarhimpunan. Bila dihubungkan dengan konsep kemampuan komunikasi matematis, maka dapat diartikan bahwa siswa terkendala dalam memodelkan situasi-situasi dengan menggunakan tulisan, baik secara konkret, gambar, grafik, atau metode-metode aljabar, yang dalam hal ini siswa belum maksimal dalam menyajikan konsep dalam bentuk gambar diagram venn.

Pertanyaan pada soal nomor 4 adalah menentukan banyak anggota himpunan, namun siswa justru menuliskan daftar anggota himpunan. dalam Ini artinya siswa kurang memahami maksud soal. Bila dihubungkan dengan kemampuan komunikasi matematis, terdapat indikasi siswa terkendala dalam memodelkan situasi-situasi dengan menggunakan tulisan, baik secara konkrit, gambar, grafik, atau metodemetode aljabar, yang dalam hal ini siswa belum maksimal dalam menyajikan data dalam bentuk daftar bilangan.

Selanjutnya, dalam menjawab soal nomor 5, siswa hanya mampu dalam memperkirakan jawaban yang benar, namun tidak dapat menjelaskan alasan dari 
jawabannya tersebut. Bila dihubungkan dengan kemampuan komunikasi matematis, terdapat indikasi siswa terkendala dalam menjelaskan ide atau situasi matematis secara tertulis yaitu dalam menjelaskan alasan dari keputusan yang telah diambilnya, yang tentunya terkait dengan kemampuan siswa dalam mengungkapkan kembali suatu uraian matematika dalam bahasa sendiri terkait dengan pengetahuan siswa terhadap materi.

Secara garis besar, kesalahan-kesalahan yang terjadi membuat skor kemampuan komunikasi matematis siswa rendah antara lain:

a. Siswa belum menguasai betul materi prasyarat, yaitu tentang konsep bilangan yang telah dipelajari di awal semester satu. Ini terlihat jelas dalam jawaban siswa pada soal nomor $2 \mathrm{a}$.

b. Siswa salah atau kurang sempurna dalam menuliskan himpunan sesuai dengan notasi yang diminta. Ini terlihat pada jawaban siswa unttuk soal nomor $2 \mathrm{~b}$ dan $6 b$.

c. Siswa kurang bisa membaca diagram venn dan menyatakannya dalam bentuk simbol matematis dan dalam bentuk soal cerita yang sesuai dengan diagram yang ditampilkan. Ini terlihat pada jawaban siswa untuk soal nomor $6 \mathrm{c}$.

Berikut adalah cuplikan jawaban siswa untuk soal nomor 2 dan 6 dalam kemampuan komunikasi matematis:

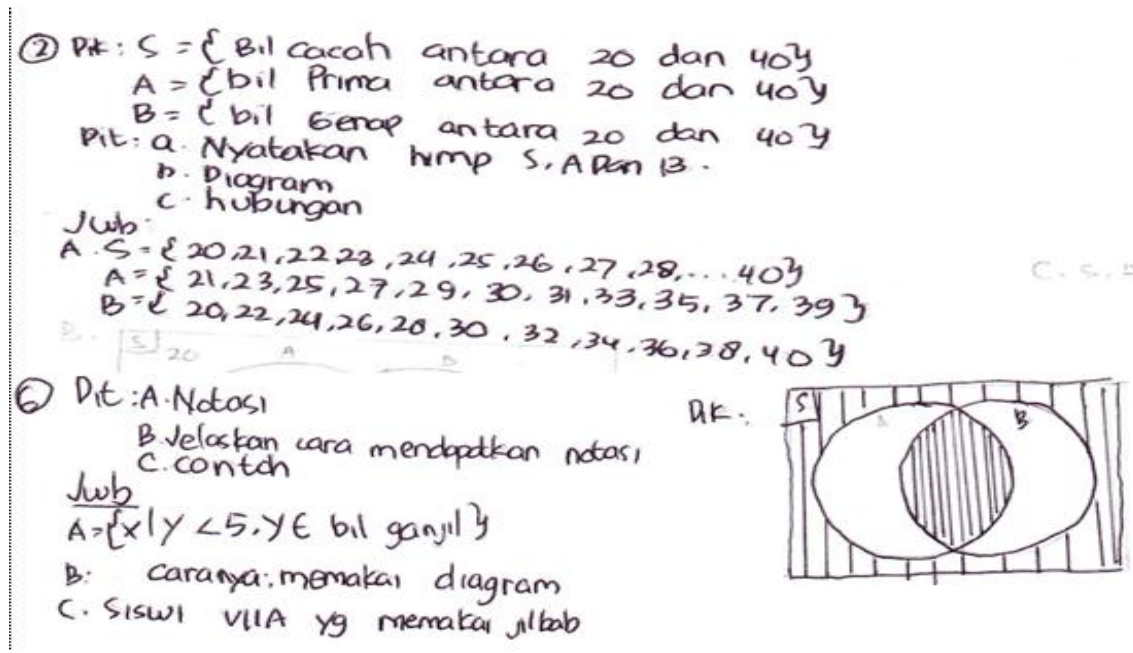

Gambar 2. Jawaban Siswa dalam Kemampuan Komunikasi Matematis 
Adapun bunyi pertanyaan untuk soal nomor 6 adalah:

f. Perhatikan diagram venn berikut ini:

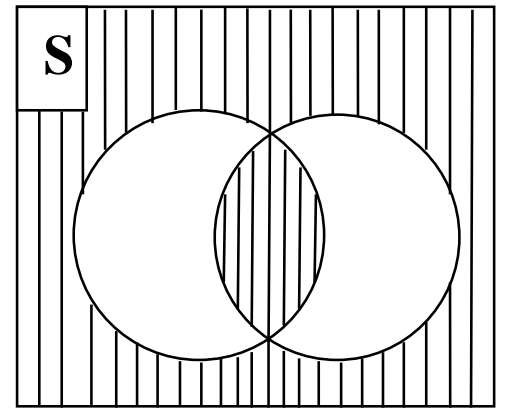

a. Tuliskanlah notasi himpunan yang sesuai untuk daerah yang diarsir pada diagram venn di atas.

b. Jelaskan cara kamu memperoleh notasi tersebut.

c. Buatlah sebuah contoh permasalahan sehari-hari yang sesuai dengan situasi pada gambar di atas.

Berdasarkan gambar di atas, pada soal nomor 6, siswa tidak dapat menuliskan notasi yang sesuai dan tepat untuk menyatakan diagram venn yang ditampilkan dalam soal. Bila dihubungkan dengan kemampuan komunikasi matematis, terdapat indikasi siswa terkendala dalam membaca dengan pemahaman suatu representasi matematika tertulis, sehingga sulit dalam menjelaskan ide atau situasi matematis secara tertulis, yaitu dalam bentuk notasi himpunan.

\section{KESIMPULAN}

Berdasarkan hasil penelitian dan pembahasan, dapat disimpulkan:

1. Terdapat hubungan positif yang signifikan antara kemampuan komunikasi dan penalaran matematis siswa secara keseluruhan (tanpa memandang level sekolah).

2. Terdapat hubungan positif yang signifikan antara kemampuan komunikasi matematis dan kemampuan penalaran matematis siswa sekolah level tinggi.

3. Terdapat hubungan positif yang signifikan antara kemampuan komunikasi matematis dan kemampuan penalaran matematis siswa sekolah level sedang.

4. Terdapat hubungan positif yang signifikan antara kemampuan komunikasi matematis dan kemampuan penalaran matematis siswa sekolah level rendah.

\section{E. REFERENSI}

Departemen Pendidikan Nasional. (2006). Panduan Penyusunan Kurikulum Tingkat Satuan Pendidikan Jenjang Pendidikan Dasar dan Menengah. Jakarta: BSNP. 
Riduwan dan Sunarto, H. (2013). Pengantar Statistika untuk Penelitian Pendidikan, Sosial, Ekonomi, Komunikasi, dan Bisnis. Bandung: Alfabeta.

Ruseffendi, H. E. T. (2006). Pengantar kepada Membantu Guru Mengembangkan Kompetensinya dalam Pengajaran Matematika untuk Meningkatkan CBSA. Bandung: Tarsito.

Supranto, J. (2008). Statistik Teori dan Aplikasi Jilid I. Jakarta: Erlangga.

Sugiyono. (2011). Statistika untuk Penelitian. Bandung: Alfabeta.

Sumarmo,U. 2010. Berpikir dan Disposisi Matematik: Apa, Mengapa, dan Bagaimana dikembangkan pada Peserta Didik. [Online]. Tersedia: http://math.sps.upi.edu/wp-content/upload/2010/02/ BERPIKIR-DANDISPOSISI-MATEMATIK-SPS-2010.pdf. [10 Mei 2011].

Siregar, Nurfadilah. (2011). Pembelajaran Geometri melalui Model Pace Berbantuan Geogebra sebagai upaya Meningkatkan Kemampuan Penalaran dan Komunikasi Matematis Siswa SMP. Tesis pada SPS UPI Bandung: tidak diterbitkan.

Wahyudin. (2008). Pembelajaran dan Model-model Pembelajaran. Bandung: UPI Press.

Wardhani,S dan Rumiati. (2011). Instrumen Penilaian Hasil Belajar Matematika SMP: Belajar dari PISA dan TIMSS. Yogyakarta : Kementrian Pendidikan Nasional : Pusat Pengembangan dan Pemberdayaan Pendidik dan Tenaga Kependidikan Matematika. 